\title{
THE FLIGHT AUTHORIZATION OF THE AUTOMATIZED VTOL UAS FOR METEOROLOGICAL SENSOR MEASUREMENT
}

\author{
Tímea VAS*, Mátyás PALIK, Zoltán DUDÁS \\ University of Public Service, Faculty of Military Science and Officer Training, Department of \\ Aerospace Control and Pilot Training, 1, Kilián str., H-5008 Szolnok, Hungary \\ Sándor SIMON \\ University of Public Service, Doctoral School of Military Engineering, 9-11, Hungária ave., H-1101 \\ Budapest, Hungary \\ Zsolt BOTTYÁN, Ármin FENDRIK \\ MouldTech Systems Ltd., 7 Fuvar str., H-8900 Zalaegerszeg, Hungary \\ *Corresponding author. E-mail: vas.timea@uni-nke.hu
}

\begin{abstract}
Considering the exponential growth of drone technology and its expected economic effect [1], the Hungarian Government called on the industrial and academic sectors for an innovative cooperation in the field of intelligent autonomous mobility. The tender was launched by the Institute of Transport Sciences Non-profit Ltd. (ITS) last December, and among the winners was the joint tender of the Mould Tech Systems Ltd., the Budapest University of Technology and Economics and the University of Public Service (UPS). The common research is focusing on the implementation of a special Vertical Take-Off and Landing Unmanned Aircraft System (VTOL UAS)-based meteorological support system which is to measure the lower parts of the atmosphere within the planetary boundary layer (PBL). The researchers of UPS are examining the legal issues of operational conditions, flight authorization, flight safety aspects concerning the identification of potential dangers, and the airworthiness issues and will formulate their recommendations. In this paper the authors introduce the numbers of issues that have to be solved in favour of the safe and legal VTOL UAS operation.
\end{abstract}

Keywords: VTOL UAS; airfield; meteorological measurement; legal issues; certification, safety

\section{INTRODUCTION}

The reliable, short- and medium-term meteorological forecasts are necessary not only for manned and unmanned aviation, but a growing demand appears from different parts of the economic sector, such as green energy settlements, transportation, agriculture, building industry etc. Nowadays meteorological data may be gained from different sources, these are usually the elements of surfacebased system, as meteorological stations, and pieces of installed measurement instrument at the airfields. Additional data providers can be the meteorological satellites - that are entitled for monitoring large-scale weather fronts and meteorological streams - microwave weather radars, lightning detection systems, and meteorological balloons mounted with radiosondes, LIDARs, etc. In Hungary the radiosondes are used to be launched only two times a day, from two different stations, and the transmitted data contain very important information about vertical distribution of temperature, humidity and wind characteristics, too. In our country three military and eight civilian airfields disseminate short- and medium-term meteorological forecasts in every 30 minutes and in three-nine hours a day, which involves the vicinity of the airfields and their landing areas.

The above mentioned meteorological data sources do not provide enough accurate information about the weather situation of the atmosphere below the PBL. Between the ground and PBL - whose height varies daily and seasonally - there is a range of different effects and phenomena, that can hardly influence the weather conditions. The surface topography, the size of residential and built-up 
areas, the soil surface quality and its radiation coefficient, the atmospheric pollution and many other factors can be responsible for actual weather situation. The more specified meteorological data can be resulted, the more predictable flight planning. The continuous data need can be supplied with regular atmospheric sensors [2][3].

On the other hand, the UAS-based meteorology will be a very important part in accurate weather prediction because it can complement the large data gap comes from the PBL and therefore we made some successful atmospheric measurement experiments in the last years [4][5][6][7]. Additionally, we also done some in-flight icing estimation in connection with UASs' with the special regard of Central European areas, too [8].

The joint tender of the above-mentioned company and cooperating universities is aimed at the construction and operation of a multi-based, automatized VTOL UA, which probes the atmosphere lower 1000-2500 metre layer every two-three hours a day. During the development and testing period, the VTOL UAS will be installed in three airfields of Hungary. Knowing the fact that the operation of an unmanned aircraft itself means potential risk for the general aviation in the air, and people and assets on the ground, researchers of UPS going to elaborate a concept of operation (ConOps) how the VTOL UAS will enter service. This concept would include conditions of legal operation, the minimum requirements of certification and suggestions for risk mitigation.

\section{DESCRIPTION OF THE VTOL UAS AND ITS TECHNICAL SPECIFICATIONS}

Although, the VTOL UAS is under development, only sub-units have been tested till now, the most important technical parameters have already known. Electrical motors of the VTOL UA are powered by LiPo-battery, which is able to lift it until the required level, and besides it must be highdegree resistant to temperature, wind, and precipitation. According to the engineers' plan, the UA has to operate between $-20^{\circ} \mathrm{C}$ and $+50{ }^{\circ} \mathrm{C}$, when the rate of relative humidity is between $5 \%$ and $100 \%$, it may operate also in strong wind, up to $20 \mathrm{~m} / \mathrm{s}$.

The the prototype's fuselage is made by polyethylene (PET), but the real product is being built by carbon fibre plastic (CF-ASA) for serial production. In both cases the 3D printing technology is going to be used (Figure 1). The Maximum Take-Off Mass (MTOM) of the aircraft is about $3000 \mathrm{~g}$ and approx. $2600 \mathrm{~g}$ excluding the payload. The aircraft is equipped with a special sensor system for meteorological measurements as a payload. The UA is powered by $2 \times 720 \mathrm{~W}$ electric motors, on the shafts of which 4 blade propellers are placed in a coaxial arrangement. The climb and descent of the aircraft is controlled by changing the rotation speed of the engines, by deflecting the 4 steering plates placed in the lower part of the fuselage in the air flow excited by the propellers, by deflecting the air flow (trust-vectoring).

For the preparation of safe flight of the VTOL UA is docked in a ground station, which must be mounted with a range of supplementary elements. After the UA completes a successful mission, which takes 20-25 minutes from departure to landing, it returns to Base Station (BS). The BS is equipped with heated battery holder, rigid cover against dust and contamination, uninterruptable power supply (UPS) for control unit and batteries, transmission unit in order to maintain contact with control station and for continuous transmission of measured meteorological data. The atmospheric temperature, pressure and relative humidity are probed through a special sensor's inlet, and continuously transmitted to the cloud-computing database by dint of Open Glider Network (OGN) or other radiofrequency-based on-board transmitter. In addition, the BS is mounted with camera system which allows visual inspection of UA. The UAS sends full telemetry to the Evaluation Centre (EC) via the internet connection (Wi-Fi / 4G or 5G). (Table 1)

Due to the regular and valid meteorological data, VTOL UA should be almost all-weather-capable, which means that it should be able to fly in clouds, within medium intensity precipitation and at night. The whole system is planned to be able for autonomous operation, however in the beginning when tests are ongoing, the system is continuously working under human control. 
The Flight Authorization of the Automatized VTOL UAS for Meteorological Sensor Measurement 3

\subsection{Operational concept}

The UAS performs its tasks in a completely autonomous manner by the operating concept, without personnel assistance. Depending on the needs of the application, the UAS will be installed near civilian aerodromes, where it will perform atmospheric reconnaissance tasks for meteorological forecasts necessary for the safe operation of airports.

Table 1 Characteristics and rate VTOL UA

\begin{tabular}{|c|c|}
\hline Characteristics & Rate \\
\hline Diameter (fuselage) & $\sim 400 \mathrm{~mm}$ \\
\hline Height & $\sim 600 \mathrm{~mm}$ \\
\hline Maximum Take-Off Mass (MTOM) & $\sim 3000 \mathrm{~g}$ \\
\hline Take-Off Mass (excl. payload) & $\sim 2600 \mathrm{~g}$ \\
\hline Altitude (max.) & $6000 \mathrm{~m}$ (AMSL) \\
\hline Duration & $\sim 20 \mathrm{~min}$ \\
\hline Communication radius & $\sim 80 \mathrm{~km}$ \\
\hline Engine & $2 \times 720 \mathrm{~W}$ electric engine \\
\hline Propulsion & 4 baled airscrew (x2) \\
\hline Power supply & 6800 mAh LiPo, 22,2 V \\
\hline
\end{tabular}

The data collected by the UAS will be transmitted to EC, where measurement data from other similarly installed devices are fed in. After the evaluation and aggregation of data, meteorological forecasts can be prepared for aviation participants. The EC is responsible for continuous monitoring and control of the whole UAS operation at each airfield.

\subsection{Certification}

The European Union (EU)[9][10] defines the new regulatory framework for UAS with a proportionate risk-based approach, with three pillars based on real classification into "open", "specific" and "certified" categories. During the certification concept, this risk-based approach should be followed, which requires a description of the VTOL drone technical data (e.g. Maximum Take-Off Mass: MTOM) and its the operational concept in order to comply with the legal requirements. An authorization procedure for obtaining an operational authorisation should be completed with participation of the competent (aviation) authority.

In our case, the pre-determined MTOM of the UA and the operating concept, which is going to be in beyond visual line of sight (BVLOS), and the fact that the planned flight altitude exceeds $120 \mathrm{~m}$ clearly defines that the UAS operation is only be classified in specific category. Before the flight operation a risk assessment should be carried out to identify the ground and airborne risks of UA operation and to formulate risk mitigation measures that the Authority finds acceptable to for the the safe flight.

The risks can be reduced in case the remote pilot is be licensed, until the flight does not relates to autonomous operation, and the organization must be authorized to operate. The risk assessment should consider the fact that the UAS itself is a prototype and its scope is specific. However, the operation of the drone cannot be classified in any of the standard scenarios defined by the EU (STS-01, STS-02) [11], as the flight altitude of the aircraft exceeds $120 \mathrm{~m}$ during its operation. The Operational Safety Objectives (OSO) for a given activity can be delimited and based on this the activity can be classified as either low- or medium- or high risk in terms of its degree of reliability. The degree of confidence is given by the combined content of the level of integrity and the degree of certainty. The level of integrity is the security objective of a given operation. The degree of certainty, however, is evidence of the extent to which the risks arising from the operation can be reduced [12][13]. 


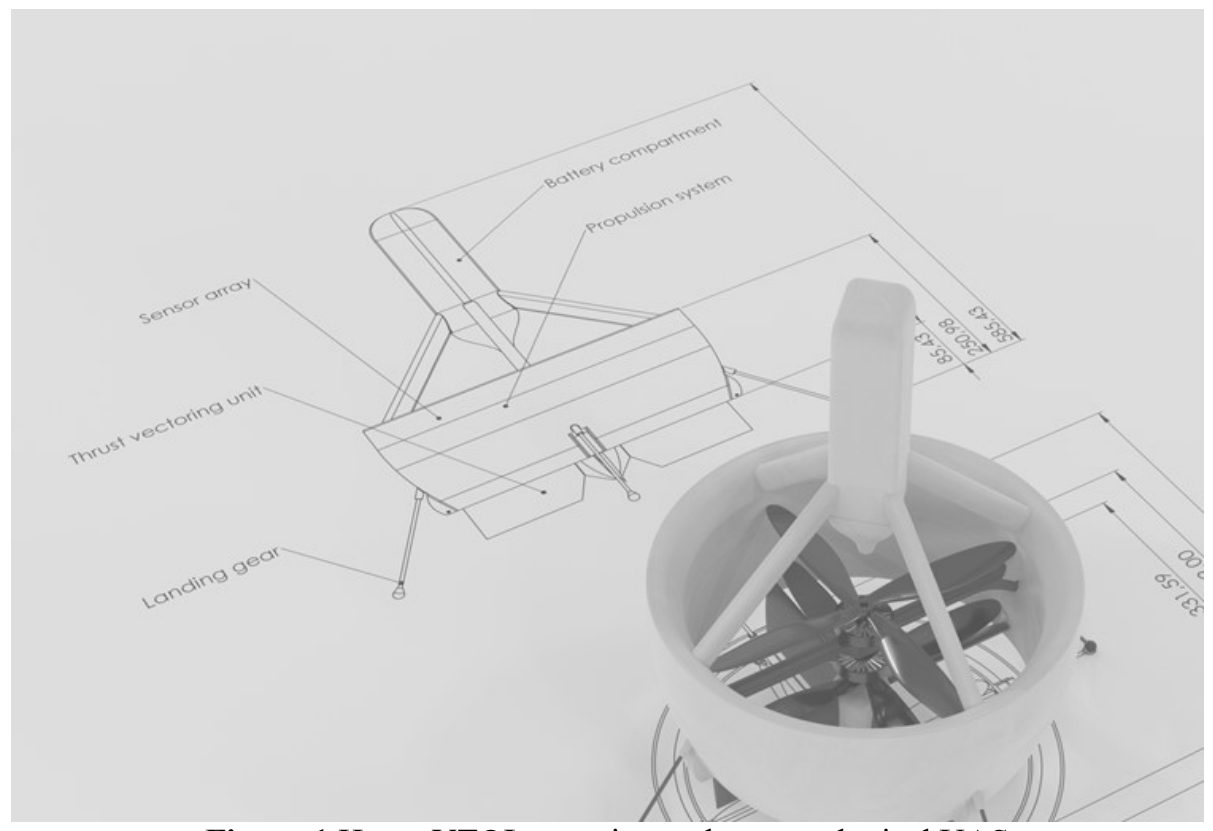

Figure 1 Horus VTOL experimental meteorological UAS

Whereas the risk assessment of UAS operations in a specific category must take into account the design and performance characteristics of the UAS with particular regard to compliance with UASrecognized standards, the concept will therefore include steps to examine and summarize design, propulsion, aerodynamic factors, payload placement, centre of gravity, kinetic energy, Detect and Avoid (DAA) and Emergency (EM) systems and tests for the reliable operation of the UAS.

In addition, in order to obtain an operational authorization, the competent (aviation) authority must certify that a competent remote pilot performs the operations with appropriate competence in the management of the UAS. The remote pilot must undergo through a certified training or achieve the appropriate level of training to operate UAS in this category. In addition, the remote pilot must be familiar not only with the technical characteristics of the UAS type but also with the characteristics of the tasks performed, particularly, the types of operations to be assessed.

In our case, the aggravating circumstance is that the UAS is designed to be a fully autonomous device, it does not have a pronounced remote pilot, and a specialist in the meteorological evaluation centre, who has the possibility to intervene if the UAS malfunctions, supervises its operation. Accordingly, in practice, he is considered a UAS remote pilot, so he must have the level of competence and knowledge required by law to operate the UAS.

When choosing the appropriate operating license, considering the characteristics of the UAS, the so-called easy to obtain a Light UAS Operator Certificate (LUC). This type of certificate is primarily an appropriate choice for organizations that typically perform one or more types of the same type of operation with high regularity. The main advantage of the permit is that after obtaining it, it is no longer necessary to re-permit the operations with the authority, but in possession of the permit, the activity can be carried out continuously with the indicated device. The main condition for this is that the organization must create an organizational manual (LUC manual) describing the operation of the organization and develop its own flight safety management system. In addition, the organization and its members must meet the requirements specified for the organization and for remote pilots within the specific

Finally, to ensure compensation for any damage caused to a third party, the operator must have insurance, which must also be presented to the authority when applying for an operational authorization. 
The Flight Authorization of the Automatized VTOL UAS for Meteorological Sensor Measurement 5

\subsection{Type certification, conformity assessment}

Based on the technical parameters and operational characteristics of the UA, in particular the operating altitude ( $\sim 6000 \mathrm{~m}$ AMSL), the legislation [9] makes it clear that the device must undergo a so-called certification. The Authority in accordance with the standards prescribed for conventional aircraft inspects the design of the UAS (conformity to type), the production conditions and the maintenance system. In possession of permits, can be said to be suitable for safe aviation.

The statutory certification procedure is a rather complex procedure that imposes a significant burden on both the production organization and the authority. For a manufacturer, it means compliance with typically flying industry standards and regulations that a small drone manufacturer may not have encountered before. Typically, during production / design, safety margins and material quality must be taken into account, which means a significant additional cost for the organization.

The situation is not easy on the part of the authorities either, as the standards and certification specifications previously applied to conventional aircraft have to be applied by regulatory authorities to the often-small unmanned aircraft. This requires practice and a detailed knowledge of the characteristics of unmanned aerial vehicles to make the system of requirements for conventional aircraft applicable to a drone.

Another certification aspect the UA should undergone the CE marking- indicates the product or the manufacturer or importer affirm the compliance with the relevant EU regulation- which is also worth proposing at this stage of the study but will indeed become due once the production and distribution of the automated meteorological UAS system starts within the EU. A significant obstacle of the applicability of this concept is that it is currently only applicable to open category devices with an operating altitude of no more than $120 \mathrm{~m}$. In this case, based on the weight of the device, it can be classified into class C2 (MTOM $<4 \mathrm{~kg}$ ) and the type conformity - instead of the authority - can be classified as a so-called conformity assessment bodies [10].

The conformity assessment body shall determine the qualification of the so-called by an accrediting authority, which examines the capacity and competencies of the organization and compliance with the system of requirements for conformity assessment bodies in the framework of an audit procedure. Following a successful procedure, the accredited organization visits the so-called a notifying authority that notifies a conformity assessment body to the Commission (EU). Following the notification, the competent body of the EU, thus obtaining the status of Notified Body (NOBO), to which a registration number is assigned, registers the conformity assessment body. Organizations holding such a license may further assess the conformity of products (drones) of organizations manufacturing unmanned aerial vehicles in that category.

A conformity assessment procedure is a procedure defined by a standard in which the UAS must be examined for compliance with the conformity requirements specified in the standard. If the tested UAS meets the requirements of the standard, NOBO will issue a certificate of conformity, the manufacturer can affix the CE marking, and class identification label to the product and accordingly the product can be marketed within the EU.

\section{FLIGHT SAFETY HAZARD AND RISK OF VTOL UAS IN AIRPORT OPERATIONS}

There are two types of risks that are traditionally mentioned associated with the presence of conventional and remote flight in the same airspace. The risk-making potential of the configuration i.e. meeting the two worlds the conventional and unmanned system in one airspace can create a variety of serious consequences. On one hand the severity of these harmful actions like: aircraft or surface objects' damage, uncontrollability of flight, mid-air collisions, crashes depend on given circumstances which may prove to be controlled. On the other hand, due to the relatively poor reliability of the UA technique, it is also worth considering the possibility of preventing the causes leading to the mentioned consequences, by improving remote systems. The application of the UAS for meteorological reconnaissance in the close vicinity of an airport promises benefits that will greatly contribute to the safety of flights by providing more accurate measurements about the different weather situations. However, weather hazards identification with using UAS, a new method has the capacity to become a 
hazard itself, creating a new breed of risk. A scientific analysis of these hazards and their consequences (collision, failure) emerged by the conventional and UAS traffic sharing the same airspace- will lead to the determination of the conditions under which this operation can contribute safely. Such an analysis should focus on the key elements of the risk: the hazard itself, the determination of the probability combined with the severity of harmful consequences. The risk of UAS presence during airfield operations is affected by several factors. For instance: poor visual perception of a UA, density of traditional traffic at the same airspace and altitude (probability range), a typical flight speed, as well as the mass, size and nature of aircraft in the airspace (severity range) should be examined in terms of collision risk elements. For UA failure, a risk analysis similar to that presented above is the most necessary to determine the probability range of reliability. The presented risk analysis (hazard, probability, severity) can lead to the development of risk management options that reduce risks and increase safety in the form of rules and technological solutions, according to Reason suggests. The applicability of these risk mitigation options, such as:

- $\quad$ special ATM procedures, flexible airspace structure;

- rules and restrictions;

- technical solutions to mitigate the consequences of UAS failure (e.g., parachutes);

- equipment for UA detection and avoidance for airspace control and conventional aircraft.

The achievements of a modern aviation industry such as remote control generated a number of new problems. The most important problem is the issue of safety, which must be guaranteed in such a way that it does not jeopardize the traditional aviation system, but also leaves room for the development of a new aviation sector. Today, UA flights have grown to such an extent that its harmonization and integration with the traditional flight system has become an inevitable and urgent task. It means the harmonization of rules, applications, airworthiness, flight permits and those requirements that are included regulatory means. The most important principle followed by regulatory organizations is to guarantee safety. When the safety comes the risk assessment cannot be avoided either, and this clearly leads to a risk-based approach [14].

The most known of the approaches which can be used to analyse aviation system is the SHEL(L) model, which is actually a multidimensional explanation of the traditional human-machine environment model. Theoretically the technical elements known as "hardware" in the system and could not be interpreted individually, but also in connection with the environmental (natural, social, cultural, organizational) factors surrounded the aviation. Also widely known is the so labelled Swiss Cheese Model (SCM), which was invented by James Reason, and shows the underlying causes of human error through an event seeing in its chronology, with a strong focus on the human factor, technology and rules, and the aircraft itself. This concept serves to improve aviation safety in three ways. It demonstrates the frames of our thinking on aviation as a system. That leads to a kind of method of analysis and an accident or incident investigation tool. The SHEL(L) model looks for the possibilities of their safety improvements in the connections of the system elements, while for the individual elements of the SCM, the latter considers the prevention of individual and organizational errors of the human factor to be primary. For the present research, the man task is to identify the hazards associated with the operation of UAS at the airport. Knowing the fact that a fully autonomous system will be built, it will be necessary to narrow our examination partly excluding of the human elements of the models, if they are considered only in terms of the probability of collision with conventional air traffic in the air (perceptibility, situational awareness) [15].

\subsection{SHEL(L) model}

The SHEL(L) model serves as a multidimensional upgraded form of the HME (human-machineenvironment) theory, in which the safety effecting elements (software, hardware, environment, livewire) are displayed as equal factors. The model focuses on quality of integration of the system components. The level of interconnections amongst them not only influence but determine the safety producing quality of the system as a whole, trough the relationship and cooperation of the system composed elements. Looking at this operational quality for safety, each connection of the elements 
increases the level of safety. Here and now excluding complete analysis of the model, it can worth making a remark that the model has evolved from the original concept insofar as it now. The model in its present form interprets the factors and the connections within it not only in themselves but also in their dimensions. This means that the model in its extended form is also able to examine the relationships within system components, so that in this case the "Hardware-Hardware" and "Hardware-Environment" relations are to be interpreted in terms of inner interactions as well. Similar to the Reason model, the effects of human and technical factors on safety are at the forefront of the study [16].

As for using the SHEL(L) model in UAS risk assumption considerable remarks on UAS operators are made by Janik, Zawistowski and Fellner [17]. They identified the key element of the system saying that according to the model it is necessary to focus on the operator of the unmanned aerial vehicle. Although this study assumes a human free, or partly autonomous system it is worth taking into consideration of keeping the possibility of human pre- and post-flight check, or on other predetermined regular basis and intervention in case of emergency. As Janik suggests that, the operator of the UA has responsibilities in the following activities for instance:

- implementation of checklist and checks;

- cooperation, and communication with observers if necessary;

- perform operations under specified weather conditions;

- checking the airspace (availability, traffic).

According to the Hungarian regulations the commander of the aircraft (in this case the UAS operator) the only one who is strictly defined as charged for the rule keeping and safe performance of the flight. A lack of any check or awareness may lead to unsafe situations even if in the unmanned domain [17]. Agreeing with that statement the question of quantity and quality of human control is a basically autonomous system must be scrutinized by future studies.

\subsection{Reason model}

The model as most widely known the SCM was developed by James Reason [18]. The central theme of Reason's research is this modern safety philosophical approach in which the development of an accident is in the focus. The basic idea of the theory is that the prevention is based on the seeking for underlying causes, which are originated from root causes as human factors and organisational shortcomings. The concept builds on the existence and exploration of deep correlations amongst safety effecting factors. The exploration aims the evolution of the harmful act and even the chain of events leading to harmful consequences, thus revealing the active failures and dormant factors as well. Those contributing factors are generally conserved in the organization and pre-encode the possibility of accidents. According to some approaches a safe technical system is the key to safety and human factor and its role in the operation of the system may be reduced by automation. The UAS is going to be operated in the vicinity of an airport and both automation both other safety measures are feasible, though we must accept that the aviation system is fundamentally unsafe, therefore, it carries risks which is not the resulted from malfunctioning of the system, but from other problems staying in deep. [19].

\subsection{Risk management methods of UAS}

Hazards in aviation are constantly present and unavoidable, but methods exist for risks mitigation. Methods provide colourful ways to handle flight safety risk reduction. These are:

- acceptance of risk;

- avoidance of risk;

- to spread risk;

- to shift risk;

- reduction of risk. 
The selection amongst the measures depends on the importance and urgency of the task as well as the circumstances. It is important to mention that risk management is always bonded to the preventive and predictive methods, which means that in the process of safety planning built-in risk mitigation ways are preferred. Having the possibility to exclude harmful factors, it seems effective to pre-assess the probability of activation of them and severity of consequences. That leads to a hazard-tailored risk management focusing the methods dealing with exposure, likelihood and severity.

The primary aim of risk management is to reduce the level of risk in accordance with the importance and urgency of the task. Acceptance is one of the most critical way of risk management. Hazards cannot be excluded entirely from aviation. It is obvious, even if we are aware or not. The level of aviation safety in all domains depends on proper risk acceptance. That leads to the specification of acceptable level risk in the long run the acceptable level of safety.

Risk avoidance can only be conducted with precisely knowing the risk in numbers. That premises having the correct probability and severity calculations before safety decisions are made. In some cases, the decision is getting simplified to a go-no-go resolution, when the assessed risk is such high that exposure must be dealt with. For this purpose, risk can be avoided by a separation from the hazards. If so the activity can be terminated, or the task can be restarted in an alternative time. This kind of solutions can easily be seen as a rigid risk management because what we do here is an extreme reduction of possibility. The risks can also be avoided in a smoother way by spreading consequently keeping away either in space for a certain period of time limiting the exposure to an acceptable level [20].

Shifting risk as a method is dissimilar to the mentioned latter methods. When there are complex technical systems in hand, it is a possible to shift a part of risk to devices. UAS presence together with conventional traffic represents a sizeable amount of collision risk. Shifting the risk in this case means a utilization of on-board prevention systems, or transponders on both sides.

Although in aviation a total risk reduction and total safety are not feasible there are methods for mitigation so as to achieve an acceptable level of safety. As it has already been mentioned, during risk assessment we need to take into consideration the probability of hazards' activation and the severity of harmful consequences. As for the methods of risk reduction, three ways are proffered which are connected to risk components as: hazard elimination by ceasing exposure; reduction of probability and/or severity of bad consequences [21].

\section{RESEARCH ON AIRFIELD'S ENVIROMENT}

There are three airfields in Hungary, which volunteer to provide scene for UAS tests. These airfields are located different parts of Hungary, one is in the western part -namely ZalaegerszegAndráshida (LHZA), the next one, called Szatymaz (LHST), is in the Southern part, and the third one, Atkár (LHAK), is in the North-Eastern part. The selection of those three different airfields and their distant from each other is reasonable for the required testing of the operations of systems. These three airfields are generally known as designated for general civil aviation. They are mainly used by sport and recreational flights, each is covered with grass, and none of them has dedicated airspace and consequently nor dedicated air traffic service. The basic prerequisite of UAS operation is to have electricity and water supply at each airfield. Since these locations are either private or municipal properties, the UAS operational permissions are easily obtainable for the required airspace reservation and for regular tests. The airfield's environmental research will focus on the traffic density and composition, in order to identify the category of users, aircraft types, and the most used flight rules. Data sources originate from Hungarocontrol's flight plan database and from the airfields' movement statistics. As a result of this analysis, a picture is compiled on the the most common usage of the airfields, the busiest period of days and years and knowing the aircraft type and categories conclusions can be made on the pilots' aviation skills, the most preferable fight planning, and the applications used for pre-flight briefing. The most important factor of UAS operations is to be transparent and known by general airspace and airfield users. 


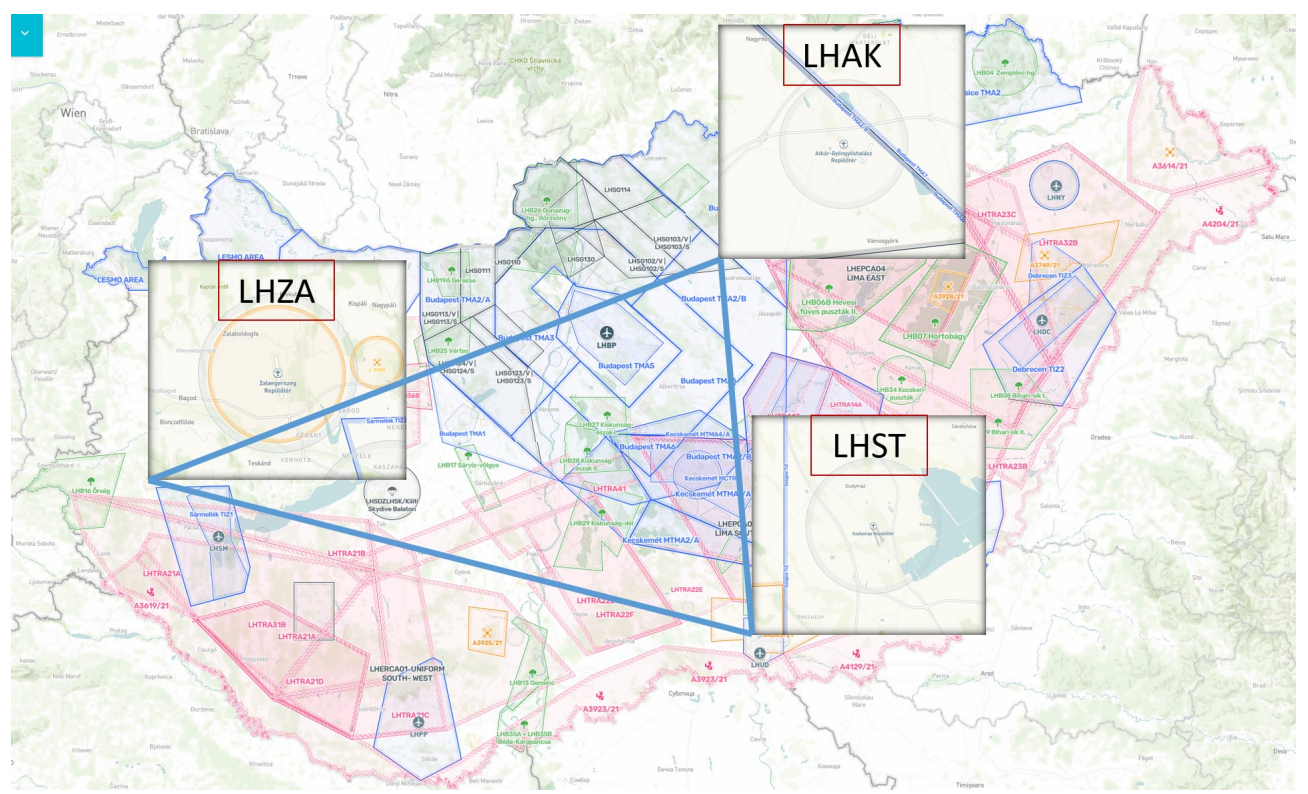

Figure 2 Airfields for planned test flights

The next focus point of our investigation is at the airfield movement area, infrastructure, obstacles, local operational procedures, departure and landing paths in order to identify those parts of the airfield which are visually well observable from the ground and from air too. In this point of the airfield, the UAS would be worth to installing. In favour of the future meteorological UAS familiarization suggestions are made on how to introduce them to general users and how to get integrate them safely into airfield operations. Another area of our investigation is involving the letter of agreements, which was made with these airfields, for example with neighbouring cities, airfields, natural parks, organizations of law enforcement or branches of air force. Our findings can list those effects that may influence the safe UAS operation. Finally yet importantly this empirical study will involve the known, reported and investigated safety occurrences concerning any of these airfields[22][23][24].

\section{CONCLUSIONS}

Going through the steps of SORA there are two consequences can be drawn, the first is that assessment is practical if a mission remains below 400', but according to similar considerations this assessment could be exceed to the higher level of operations. Although in recent legal conditions the only solution for the rightful mission of this meteorological use case if it happens within segregated airspace. So that a goal of ours is to find and offer other, much more flexible solutions, which harmonize with digital airspace management applications.

Our second conclusion refers to the description of UAS and its use which generates the question whether this flight is executable in framework of specific category or not. According to the guidance material [25] of European regulation the boundary between "specific" and "certified" operation on the one hand lies in the competency of the remote pilot, the certified airworthiness of UA and UAS operator unless the UAS is fully autonomous. On the other hand, this difference is also defined with distinction between the automatized and autonomous operation. This guidance explains that the operation is considered autonomous if the remote pilot has no ability to intervene in the course of the aircraft and considered automatic if the operation following pre-programmed instructions that the UAS executes while the remote pilot is able to intervene at any time. If this operation stated partly or fully autonomous, the UA should be equipped with emergency kits, or solutions for that case. Our research group also examines the procedures of system authorization process [26], because the VTOL UAS meteorological system's operational objective is a release from independently in time and in location of each other and the operation is monitored from one centre. The point is that neither European and nor other international regulations allow multi-UAS flights with controlling one remote pilot.[27] 
Our research should seek such international examples, good practises that are similar to this BVLOS UAS operation, regardless of their use cases. The first phase of our research lasts until the end of this year and the next one, which named the implementation phase, our task, is to control the viability of our recommendations.

\section{Acknowledgement}

This work was supported by the Ministry of Innovation and Technology and KTI Institute for Transport Sciences Non-profit Ltd. (KTI_KVIG_7-1_2021, "Development of a Complex Drone-based Meteorological Support for Autonomous Vehicles".

\section{References}

[1] Alamouri, A. - Lampert, A. - Gerke, M.: An Exploratory Investigation of UAS Regulations in Europe and the Impact on Effective Use and Economic Potential; Drones 2021., 5, 63. https://doi.org/10.3390/drones5030063

[2] Fekete, Cs. - Gajdos, M. - Bottyán, Zs. - Palik, M.: Establishment and legal preparation of a Hungarian UAS meteorological research project at a military airport In: The 15th International Conference on Intelligent Unmanned Systems Peking, China 2019. 96 p. pp. 45-45., 1 p.

[3] Bottyán, Zs. - Szilvássy, L. (ed.): A pilóta nélküli repülőeszközök meteorológiai alkalmazásának lehetőségeiről I. Az időjárás-felderítés, Repüléstudományi Szemelvények: A közfeladatot ellátó repülések meteorológiai biztositásának kérdései, Szolnok, Magyarország: Nemzeti Közszolgálati Egyetem Katonai Repülö Intézet 2017. 152 p. pp. 7-26., 20 p.

[4] Bottyán, Zs.: International and Hungarian Applications of Unmanned Aircraft Systems in the Meteorological Researches. In: Bottyán, Zs. - Szilvássy, L. (ed.) Repüléstudományi Szemelvények: A közfeladatot ellátó repülések meteorológiai biztositásának kérdései. Szolnok, Magyarország: Nemzeti Közszolgálati Egyetem Katonai Repülő Intézet 2017. 152 p. pp. 51-74., $24 \mathrm{p}$.

[5] Bottyán, Zs. \& et al.: Measuring and Modeling of Hazardous Weather Phenomena to Aviation Using the Hungarian Unmanned Meteorological Aircraft System (HUMAS). Időjárás / Quarterly Journal of the Hungarian Meteorological Service 2015. 119: 3 pp. 307-335. , 29 p.

[6] Bottyán, Z. - Wantuch, F. - Gyöngyösi, - A, Z.: Forecasting of Hazardous Weather Phenomena in a Complex Meteorological Support System for UAVs. Journal of Unmanned System Technology. 2014. 2: 2 pp. 18-25., 8 p.

[7] Bottyán, Z \& et al.: Development of a Complex Meteorological Support System for UAVs. World Academy of Science Engineering and Technology 2013. 7: 4 pp. 646-651., 6 p.

[8] Bottyán, Zs.: In-flight Icing Characteristics of Unmanned Aerial Vehicles during Special Atmospheric Condition over the Carpathian-basin. ACTA Geographica Debrecina Landscape and Environment. 2014. 7: 2 pp. 74-80., 7 p.

[9] EUR-Lex: EU 2019/947 VHR (2019.05.24.) on the rules and procedures for the operation of unmanned aircraft; Available at: https://eur-lex.europa.eu/legalcontent/EN/TXT/PDF/?uri=CELEX:32019R0947\&from=EN

[10] EUR-Lex: EU 2019/945 FR (2019.0312.) on unmanned aircraft systems and on third-country operators of unmanned aircraft systems Available at: https://eur-lex.europa.eu/legalcontent/HU/TXT/?uri=CELEX:32019R0945

[11] Corus: U-space ConOps Annex A: Use Cases Explanatory research SESAR Corus U-space Available at: https:/www.sesarju.eu/sites/default/files/documents/uspace/CORUS\%20ConOps\%20vol1.pdf

[12] ConOps Annex C1: SORA example Explanatory research SESAR

[13] JARUS: Guidelines on Specific Operations Risk Assessment (SORA)

[14] Dudás, Z. - Restás, Á.: Nemzetközi példák az UAV repülés emberi tényezőit érintő jogi szabályozásra az RPAS 2012 konferencia tapasztalatai alapján: Kockázatkezelési elvek megvalósulása a szabályozásban. Repüléstudományi Közlemények. 2012. 24: 3 pp. 1-10., 10 p. 
The Flight Authorization of the Automatized VTOL UAS for Meteorological Sensor Measurement 11

[15] Dudás, Z.: A humán tényezők és a CRM elvek jelentősége a távirányítású pilótanélküli légijármüvek müveleteiben. Repüléstudományi Közlemények. 2013: 2 pp. 314-327., 14 p.

[16] Dudás, Z.: Repülésbiztonság emberi hiba nélkül? Repüléstudományi Közlemények. 2017. XXIX 1 Pp. 75-82., 8 P.

[17] Paweł Janik, Maciej Zawistowski, Radosław Fellner and Grzegorz Zawistowski: Unmanned Aircraft Systems Risk Assessment Based on SORA for First Responders and Disaster Management. Applied Sciences MDPI 2021

[18] Reason, J.: Human error: models and management. BMJ 2000 Mar 18; 320 (7237): 768-770.

[19] Dudás, Z.: Interpretations of Human Error in Aviation. Repüléstudományi Közlemények. 202133: 1. 49-57., 9 P.

[20] Dudás, Z.: Basics of flight safety risk. Hadmérnök 2007. 2: 144-150., 7 p. (2007)

[21] Pokorádi, L.: A kockázat kategóriái. Új Honvédségi Szemle, 1996. Zrinyi 1999/6. p. 28-35

[22] Palik, M.; Vas, T.: Biztonságirányítási rendszer alapelvei az UAS üzemeltetésben, In: Békési, B. - Szilvássy, L. (ed.) Repüléstudományi Szemelvények. 2016. Szolnok, Magyarország, Nemzeti Közszolgálati Egyetem Katonai Repülő Intézet 232 p. pp. 113-124., 12 p.

[23] Daeil J, -Yongjin K Development of Autonomous VTOL UAV for Wide Area Surveillance, Department of Industrial Engineering, College of Engineering, Ajou University, Suwon, South Korea, World Journal of Engineering and Technology, 2019, 7, p. 227-239

[24] Zbyšek Korecki et.al: Use of Unmanned Aerial Systems in Airport Operations, In: 2021 International Conference on Military Technologies (ICMT). Brno, Czech Republic, 8-11 June 2021

[25] EASA: Acceptable Means of Compliance (AMC) and Guidance Material (GM) to Commission Implementing Regulation (EU) 2019/947 Available at: https://www.easa.europa.eu/sites/default/files/dfu/AMC\%20\%26\%20GM\%20to\%20Commissio n\%20Implementing\%20Regulation\%20\%28EU\%29\%202019947\%20\%E2\%80\%94\%20Issue\%201.pdf

[26] Matteson, S.: Autonomous versus automated: What each means and why it matters why it matters The Future of autonomous driving technology June 7, 2019,

[27] FAA: Small Unmanned Aircraft Systems (UAS) Regulations (Part 107). Available at: https://www.ecfr.gov/current/title-14/chapter-I/subchapter-F/part-107

Received 10, 2021, accepted 11, 2021

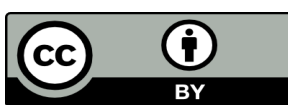

Article is licensed under a Creative Commons Attribution 4.0 International License 